\title{
How the personal support networks of people with intellectual disability promote participation and engagement
}

\author{
Kathy Shelley \\ University of Sydney \\ Michelle Donelly \\ Southern Cross University
}

Anne Hillman

University of Sydney

Angela Dew

University of NSW

Louise Whitaker

Southern Cross University

Roger J Stancliffe

University of Sydney

Marie Knox

University of Sydney

Trevor Parmenter

University of Sydney

\begin{abstract}
Background: Social inclusion has been defined as an interaction between major life domains, including interpersonal relationships and community participation among other factors. Understanding the manner in which these life domains may inter-connect could inform efforts to promote social inclusion. This paper explores the role of personal support network members in establishing and maintaining community participation of a person with an intellectual disability.

Method: An ethnographic research design allowed exploration of network interactions over a three-year period. In-depth interviews and participant observations were undertaken with nine people with an intellectual disability and their network members.

Results: The networks promoted participation using various strategies. The person and their network gathered and shared information to determine what was meaningful to the person. Information about success was used to adapt developing strategies, enhance support, and build on existing gains.

Conclusions: Personal networks provided insight into the practical and relational aspects of participation, and the importance of balancing risk and autonomy, vulnerability and freedom. Respect for the personhood, importance and dignity of each person at the centre of the network influenced this work.

Keywords: Intellectual disability, participation, networks, support, relationships, community living, reciprocity
\end{abstract}

Corresponding author: Michelle Donelly (michelle.donelly@scu.edu.au) 
Due to the diverse theoretical and discipline perspectives engaged with the concept of social inclusion, there is ongoing debate regarding what defines social inclusion (Briggs \& Harris, 2017). In a systematic review of the literature, key domains of social inclusion were identified as: participation; social connectedness and a sense of belonging; and citizenship and rights (Cordier, et al., 2017, p. 4). People with intellectual disabilities experience significant risk of social exclusion and segregation from the formal structures and institutions of the economy, society and state (Somerville, 1998), including social isolation and impoverished interpersonal interaction and community participation (Asselt-Goverts, Embregts \& Hendricks, 2013; Bigby, 2008; Briggs \& Harris, 2017; Emerson, 2011; Forrester-Jones et al., 2006; McConkey \& Collins, 2010; McVilly, Stancliffe, Parmenter \& Burton-Smith, 2006; Milner \& Kelly, 2009). The focus of this inquiry was on the relationship between two key dimensions of social inclusion in the lives of people with an intellectual disability: social connectedness and community participation.

Interpersonal relationships, as a dimension of social connectedness and community participation, are dominant considerations in the literature regarding the social inclusion of people with an intellectual disability (Simplican, Leader \& Kosciulek, 2015). People with intellectual disability, their personal network members, and formal service providers agree that participating in a variety of community activities provides opportunities to develop self-esteem, exercise self-determination, and feel good about oneself (Arvidsson, Granlund \& Thyberg, 2008; Axelsson, Imms \& Wilder, 2014; Forrester-Jones et al., 2006; O'Brien, 1987, 1999; Verdonschot, de Witte, Reichrath, Buntinx \& Curfs, 2009b). However, how this might work is not well understood or established empirically.

\section{Participation}

A systematic review of the environmental factors impacting on community participation of people with intellectual disability reported little agreement in the literature on the definition of 'community participation' (Verdonschot et al., 2009b; Zakrajsek, Hammel \& Scazzero, 2014). These authors advocated using the definition of participation employed in the World Health Organization's (WHO, 2001) International Classification of Functioning, Disability and Health (ICF). 'Participation' in the ICF is defined as involvement people have in a social context in four social life domains: (1) domestic life; (2) interpersonal life (formal and informal relationships, family and intimate relationships); (3) major life activities (e.g., formal and informal education; paid and unpaid employment); and (4) community, civic and social life (WHO, 2001). Participation is identified as "actual involvement in specific life situations, the lived experience in a social context, and should be distinguished from the skills needed to perform different activities and also, e.g. from a purely emotional sense of belonging" (Arvidsson et al., 2008, p. 277). Arvidsson et al. (2008) identified 15 factors influencing participation (see Table 1). Successful community participation also involves consideration of personal and social factors and may involve intervention by others with the person's best interests at heart.

Table 1: Factors influencing participation according to Arvidsson et al. (2008)

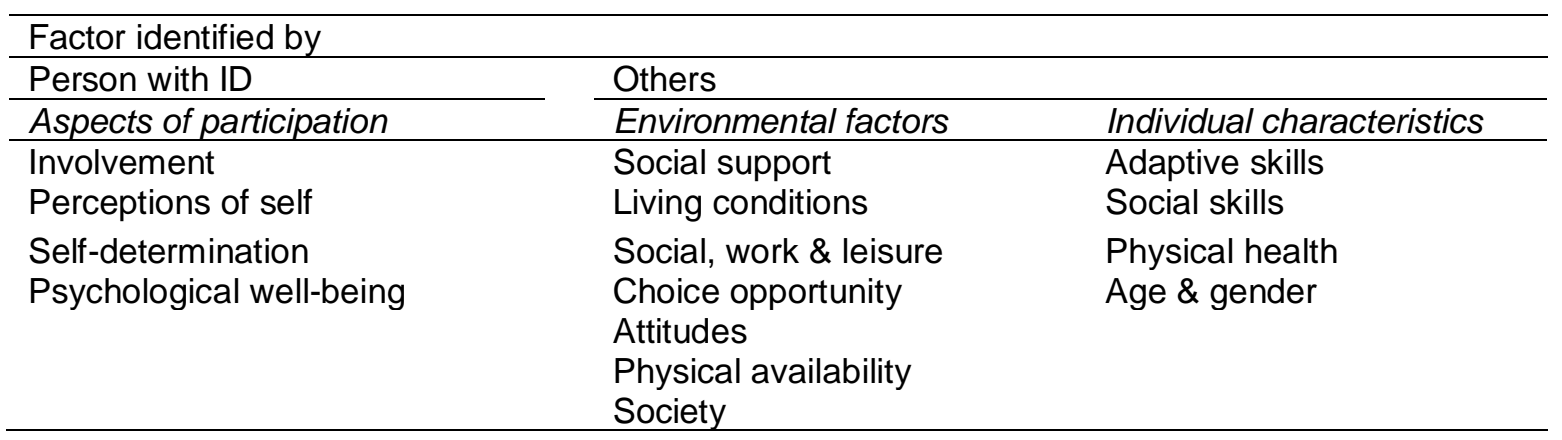


Verdonschot et al. (2009b), identified 10 positive and two negative environmental influences affecting community participation of people with intellectual disability (see Table 2).

Table 2: Environmental factors promoting participation according to Verdonschot et al. (2009b)

\begin{tabular}{ll}
\hline Positive environmental factors & Negative environmental factors \\
\hline Choice making opportunities & Lack of transport \\
Environmental variety and stimulation & Not feeling accepted \\
Opportunities for involvement in policy making & \\
Small-size of residential facility & \\
Opportunities for autonomy & \\
Work opportunities & \\
Social support & \\
Family involvement & \\
Assistive technology & \\
Positive staff attitudes & \\
\hline
\end{tabular}

Opportunities for choice, social support and attitudes are important environmental variables influencing community participation (Amado, Stancliffe, MCarron \& McCallion, 2013; Arvidsson et al., 2008; Axelsson et al., 2014; laquinto, 2016; Verdonschot et al., 2009). Also, ensuring that tasks, activities and routines occurring in the community are consistent with the person's needs and interests, and therefore engaging or personally meaningful and connect the person in a social context (Baum \& Christiansen, 2015; Bigby, 2012; Chapparo \& Ranka, 1997).

\section{Social connectedness}

Some authors argue that social context not only shapes the person's life but defines it (Etmansky, 2004; Iwama, 2006; Kronenberg, Algado \& Pollard, 2004). While links between health and well-being, engagement in tasks, activities and routines, and social context are recognised (Marmot, 2005; Oliver, 1990; Simplican et al., 2015), the dynamics of these relationships are less well established empirically. Research is needed to understand how the features of social context may build, sustain and promote participation (Schofield, 2015; Simplican et al., 2015).

Although a person may be physically present; they may not be actively engaged in the community (Ager, Myers, Kerr, Myles, \& Green, 2001; Bigby, 2012; Clement \& Bigby, 2009; Verdonschot, de Witte, Reichrath, Buntinx, \& Curfs, 2009a). Engagement was found to be dependent on individual and service factors for people living in community based supported accommodation (Kozma, Mansell \& Beadle-Brown, 2009; Myers, Ager, Kerr \& Myles, 1998; Verdonschot et al., 2009a). People who live with their parents may experience an environment which is both nurturing and insular (Myers et al., 1998). It seems clear that location of living environment is but one element in promoting community participation as well as the wide diversity of support needs and contexts of support experienced by this population group.

Acceptance of people with intellectual disabilities is an important and under-reported aspect of community participation. Younger, better educated survey participants with regular contact with people with disability were found to express more positive attitudes (Ouellette-Kuntz, Burge, Brown \& Arsenault, 2010; Yazbeck, McVilly \& Parmenter, 2004). While neighbours were reported as accepting of people's right to live in the community, neighbours found it difficult to connect on a personal level as interactions were mediated through care staff (Van Alphen, Dijker, Van Den Borne \& Curfs, 2010). Cummins and Lau (2003) argued that participation had little impact on people's quality of life due to the stigma, discrimination and prejudice encountered in the community. Attempts at participation can consequently be isolating and stressful (Meininger, 2013). Cummins and Lau proposed that "community 
connectedness" (2003, p. 151), defined as a sense of personal interdependency and belonging, is more worthwhile than attendance at community-based organizations.

People may experience difficulties in knowing how to access community activities, and may face discrimination when they seek to join community organisations (Cummins \& Lau, 2003). People with intellectual disabilities may therefore need the assistance of others in addressing discrimination and participating in the community (Clement \& Bigby, 2009; McConkey \& Collins, 2010; Myers et al., 1998). Personal support network members can be an important source of assistance and may have an advantage over paid workers in promoting community participation because, as family and friends with a continuity of relationship with the person, they may have greater insight into what is personally meaningful (Etmanski, 2004; Heller, Miller, \& Hsieh, 2002), and are able to be more creative in their approach because they are not constrained by service rules and regulations. The perspectives, opinions and experience of people with intellectual disability themselves are central to movement beyond mere physical presence to meaningful engagement (Bigby, 2012). Research is needed which explores the complex dimensions of participation in the lives of people with intellectual disability in inclusive community contexts and beyond the barriers inherent in prevalent models for the delivery of paid formal services (Amado et al., 2013).

This paper explores the role of personal support network members in establishing and maintaining the participation of a person with intellectual disability in their communities, through their lived experience. People with intellectual disability participating in this study will be referred to as the 'person'. Their personal support network will be referred to as their 'network', and personal support network members will be referred to as 'network members'. All the roles identified in the results are in relation to the person with intellectual disability at the centre of the network.

\section{Method}

An ethnographic research design (Baszanger \& Dodier, 2004) was adopted to explore the intricacies of network interactions over a three year period of data collection (Knox, Savage \& Harvey, 2006). This approach was adopted in order to follow the conceptualization, development, maintenance and impact of the personal networks; to understand these experiences in their social context; and to identify the shared values and meanings that informed the perspective of insiders (Baszanger \& Dodier, 2004). Ethical approval was obtained from the University of Sydney Human Research Ethics Committee (ECN 022007/9680). Informed consent was obtained from each person and his or her network members.

\section{Recruitment of research participants}

Family members actively thinking about and planning the future of an adult with intellectual disability were invited to participate. Nine people with intellectual disability were recruited with their network members. At the commencement of the study one of the networks was well established and had been functioning for over a year, others had just been established or were being proposed. The networks included: family members (e.g., parents, brothers and sisters); and community members (e.g., neighbours, peers and friends of the person, friends of their family, people from leisure and interest groups, employment and recreation programs, health professionals and support workers). The networks were diverse in composition and did not follow one model, although some families referred to or adopted the 'circles of support' approach (Resourcing Families, 2015; Snow, 1998).

At recruitment, the people ranged in age from early 20 s to late $40 \mathrm{~s}$, with diverse living, employment and support arrangements across inner and outer metropolitan areas in 
Queensland and New South Wales (Hillman et al., 2013). Participants' personal support networks included nine family groups comprised of five couples and four single-parent or divorced parents. Parents ranged in age from early middle adulthood to late adulthood.

\section{Data collection}

Data collection occurred via interviews and participant observations over a 32-month period in order to follow the processes of network conceptualization, development and influence. Over 60 open-ended, semi-structured interviews were conducted with individual network members (Fontana \& Frey, 2005; Holstein \& Gubrium, 2004; Spradley, 1979). Interviews explored the everyday lives, relationships, current support of and future planning for the person with intellectual disability (the person) at the centre of the network. In addition, 53 occasions of participant observations allowed us to identify and describe the daily lives of the person and their networks and participation in a variety of environments, including home, work, community and leisure as well as network meetings (Angrosino, 2005; Baszanger \& Dodier, 2004; Spradley, 1980). Participant observations ensured that perspectives, experiences and community connections of the person were explored (Tedlock, 2005). Field notes and interviews were transcribed for analysis and kept in password-protected computer files.

\section{Data analysis}

The experiences of network participants were analyzed through specification, rerepresentation, and subsequent examination of the most salient elements of their relations (Clarke, 2005; Grbich, 2007). Phases of the research were made explicit to participants and each aspect of the emerging findings extensively member checked (Donelly et al., 2010). Congruent with the purpose of our research, "conditional elements of the situation are specified in the analysis as they are constitutive of it, not merely surrounding it or framing it or contributing to it" (Clarke, 2005, p. 30). The weekly data meetings, involving at least three team members, ensured ongoing audit, review and discussion of the processes used and data obtained, and safeguarded against the dominance of any one perspective in the analysis of the data (Guba \& Lincoln, 2005; Miles \& Huberman, 1984).

We employed a number of analytic tools derived from grounded theory, acknowledging Strauss's (Corbin \& Strauss, 2008; Glaser \& Strauss, 1967; Strauss, 1987) contribution to the conceptualization of social organization and our understanding of relationships underlying situations. However, we sought with Charmaz (2005, p. 510) to "reclaim these tools from their positivist underpinnings by addressing the concepts of perspective, reflexivity, difference and the universality of theory in our analytic frame". Qualitative data analysis software (QSR NVivo) was used to assist in the task of managing the large datasets across multiple researchers and to keep memos of the ongoing evolution of nodes and team discussions of the analysis. Elements of rigour in this inquiry included prolonged engagement, persistent observation, inclusion of diverse stakeholder perspectives, and the extensive use of member checking (Guba \& Lincoln, 2005).

\section{Findings}

The details of composition, operation and actions of each personal network were unique to each person, their family relationships, culture and circumstances surrounding that person. Networks in this study used the strength of relationships as the context and key to understanding needs and developing supports. Through various channels of communication, the person and their network identified which choices, roles, skills, interests and needs were meaningful, and based planning on this information. Possibilities for community participation were investigated, discussed and sometimes established by the network. Support was provided in various ways as illustrated in Table 3. Feedback on the success of support allowed 
the networks to re-structure support. Maintenance of the network was crucial to the continuity of support and successful participation by the person. Increasing participation was evident in diverse role performance, autonomy, the person's experience of a good life and reciprocity in relationships. This was celebrated by the network, and motivated network members.

The networks developed different strategies to support successful participation and engagement. Each network was underpinned by one or more relationships based on a deep appreciation of the person. Consequently, support was offered by friends and extended family network members as well. Table 3 gives examples of how support for particular health-related issues was embedded within relationships. Each row within the table relates to a particular person. Issues relate to seven different persons (one person is listed twice) and $\leftrightarrow$ is intended to indicate a two-way relationship.

\section{Table 3: Support is provided within the context of relationship}

\begin{tabular}{|c|c|c|}
\hline Nature of relationships & $\begin{array}{l}\text { Challenges } \\
\text { identified }\end{array}$ & Strategy \\
\hline $\begin{array}{l}\text { Mother } \leftrightarrow \text { mother's } \\
\text { exercise scientist } \leftrightarrow \\
\text { exercise scientist's } \\
\text { student }\end{array}$ & $\begin{array}{l}\text { Diabetes } \\
\text { Overweight }\end{array}$ & $\begin{array}{l}\text { Exercise Science and Nutrition student had a knowledge } \\
\text { of diabetes and its implications for exercise. The student } \\
\text { met the person after work twice a week to exercise for } \\
\text { an hour. }\end{array}$ \\
\hline $\begin{array}{l}\text { Mother } \leftrightarrow \text { person's } \\
\text { sisters } \leftrightarrow \\
\text { person's niece } \\
\leftrightarrow \quad \text { whole network }\end{array}$ & $\begin{array}{l}\text { Overweight } \\
\text { Eating } \\
\text { unhealthy } \\
\text { food }\end{array}$ & $\begin{array}{l}\text { The network held a "Biggest Loser" weight-loss } \\
\text { competition, with monthly weigh-ins, team colours and } \\
\text { prizes donated by competitors and network members. }\end{array}$ \\
\hline Support coordinator & Overweight & $\begin{array}{l}\text { The person joined a soccer club started by parents } 20 \\
\text { years previously, went swimming/walking in water with a } \\
\text { friend, and became a member of a local gym. }\end{array}$ \\
\hline $\begin{array}{l}\text { Hairdresser } \leftrightarrow \text { local } \\
\text { community contacts }\end{array}$ & $\begin{array}{l}\text { Lack of } \\
\text { exercise }\end{array}$ & $\begin{array}{l}\text { Person's hairdresser recommended a local gym and } \\
\text { gave the person a pass for five complementary } \\
\text { sessions. }\end{array}$ \\
\hline $\begin{array}{l}\text { Father } \\
\text { Brother } \leftrightarrow \text { brother's } \\
\text { girlfriend }\end{array}$ & $\begin{array}{l}\text { Person } \\
\text { wanted a } \\
\text { change of } \\
\text { exercise }\end{array}$ & $\begin{array}{l}\text { The person already played tennis twice a week. Her } \\
\text { father had given her boxing gloves and a bag and was } \\
\text { going to find a boxing or athletics class she could attend. } \\
\text { Her brother's girlfriend showed her some 'moves'. }\end{array}$ \\
\hline $\begin{array}{l}\text { Parents } \leftrightarrow \text { five or six } \\
\text { network members }\end{array}$ & $\begin{array}{l}\text { Exercise } \\
\text { within a } \\
\text { controlled } \\
\text { social } \\
\text { context }\end{array}$ & $\begin{array}{l}\text { The family initiated barbecues at the person's home, } \\
\text { with karaoke, cricket and humour. Attendees chosen } \\
\text { knew the person and the level of conversation with which } \\
\text { he felt comfortable. }\end{array}$ \\
\hline Boyfriend & $\begin{array}{l}\text { Exercise } \\
\text { needed after } \\
\text { foot surgery }\end{array}$ & $\begin{array}{l}\text { The person and her boyfriend went walking while she } \\
\text { recovered from foot surgery. }\end{array}$ \\
\hline $\begin{array}{l}\text { Support coordinator } \leftrightarrow \\
\text { support coordinator's } \\
\text { friend who runs street } \\
\text { soccer program } \\
\leftrightarrow \quad \text { soccer players }\end{array}$ & $\begin{array}{l}\text { Maintain } \\
\text { healthy } \\
\text { weight } \\
\text { Person } \\
\text { played by } \\
\text { unconven- } \\
\text { tional rules }\end{array}$ & $\begin{array}{l}\text { Person attended a street soccer program which is } \\
\text { situated in a recreational centre. The person had the } \\
\text { freedom to take part as he wished, and was accepted by } \\
\text { the other players who encouraged him to join in. }\end{array}$ \\
\hline
\end{tabular}

Note: The $\leftrightarrow \square$ symbol signifies a personal connection of a network member was involved in creating an opportunity. 


\section{The process of support}

The person and their network pooled information to determine what was meaningful to the person. Network members asked direct questions, listened to the person's views in both formal and informal settings and, knowing the person well, could pick up cues that indicated the person's choices, strengths and obstacles. Knowledge, experience and individual qualities were applied to the task of planning participation based on what was meaningful. New options for participation in the community were investigated and assessed. Networks sometimes brought the community to the person and re-educated community members. The network provided comprehensive, individually appropriate support for the person's engagement and participation that was personally meaningful and likely to connect the person to a social context. Information about success was used to adapt developing strategies to enhance support and build on existing gains. Each of these support processes are listed below with specific illustrative examples.

\section{Asking questions of the person to gain an accurate picture}

Networks consulted with the person to identify choices, roles, interests and needs on which planning could be based. Careful listening clarified the person's choices, and reasons behind choices. This communication may have taken place within a formal meeting of the network, or as an exchange between two people during a chance social encounter, the knowledge being pooled later. It may have concerned a decision as major as moving house or as minor as choice of ride at a theme park.

During a network discussion about one person's move away from home, her brother suddenly turned to her and asked, is this really what you want to do? Her sister added, if you don't want to do this, we could stop. The person thought for a while then said it was what she wanted to do. Network members noticed... a growth in assertiveness and confidence. Gaining this person's input continued to be a top priority in planning meetings. [Person has always been present in the group and it's her group and she's usually read out a little report about her past six weeks and ... what she'd like and what she wouldn't like...]

Network members stayed alert for signs that indicated meaning and choices for the person, particularly if non-verbal communication was common. One network member talked about the depth of knowledge required for adequate support. If [she] was going to live independently...a full life, what are the supports she's going to need and what are the skills and strengths that we can actually work on and improve and if she has any weaknesses, can we teach them, can we build, put something in place?

\section{Identifying strengths}

Networks also identified the person's skills, talents and personal qualities. A mother said, she's always liked cooking so ...she did some work experience at a nursing home. It was in the kitchen helping with the morning teas. The person gained a Statement of Attainment in Food Preparation. Her mother commented, We're hoping that that will give her the confidence...to... do her Certificate I or II in food prep. That will then give her the opportunity of working in some kind of kitchen.

This person was an excellent social organizer, able to connect peers to social groups and supply information about social activities, while managing to protect her own confidentiality and privacy.

She loves organizing things. She does need some support in some areas because she can go off track or sometimes she forgets that what she wants isn't necessarily what everyone else wants...but yeah, she would be great at organizing a social group. 
Networks built on the personality and gifts of the person to create socially valued roles. Another person loved art and at art studio class she became totally immersed, concentrating on her art. This person also had a talent for communicating with people. The coordinator said that she no longer needed a supporter at church, as she had got to the point where she'll introduce people to people. Likewise, at the art studio, attendees included some people with mental illnesses. The coordinator stated, [the person] can help those people and that really helps me...so there is a compassion coming through there...

\section{Recognising obstacles}

Some skills needed refining to ensure proficient participation. One person talked about a program she attended where she learnt how to deal with unexpected everyday situations. If you want to...find out, all about when you leave home... if something's wrong ...you don't know what to do...they teach you about it...or if you have an accident or something.

Another network struggled with trying to move the person into work programs. None of it worked, hopeless...so now he's moved to a different community participation program ...trying to build in some voluntary work...living skills... and exercise too.

In some cases, former life experiences such as vilification or abuse, or communication barriers, created obstacles to participation for the person. Network members shared ideas to overcome these obstacles. A mother told us that his life was restricted and his way of dealing with that is that he's withdrawn and that's one of the barriers that we have to try and overcome...to have [the person] know that he is a person within...a community and...a society...he has a responsibility to respond to other people. This mother tried to encourage the person to greet people when they come and to also say good-bye. She asked the staff at his house and the day centre to do the same. She said, eye contact is... difficult to establish. It's improving, getting much better.

\section{Planning and support based on qualities, knowledge and experience}

Having identified what was meaningful to the person, interests and choices, skills and qualities, and possible obstacles, the network members started to plan for participation. Network members researched opportunities in the wider community. These included groups, facilities, businesses or programs. Network members remained alert for useful contacts, chance encounters or information that may lead to suitable options. Network members pooled specialized expertise and connections to the wider community. Planning for support and providing support informed each other and often happened simultaneously. Sometimes an incident of support occurred spontaneously and became a basis for further planning. Support could not be neatly divided sequentially into planning and provision, but frequently overlapped.

\section{Linking with existing opportunities}

A father talked about how the network helped a person who had just moved out of home to link with community opportunities, so that eventually she would do this independently and receive any support she needed from her personal network. We're covering pretty much everything at the moment, he said, attend Mass on the Sunday...we're doing the follow-up on the gyms...singing...I think in time one of her singing group will make sure she doesn't miss out...her doctor's in the same location...her hairdresser's in the same location ... [the person] talks of it, dear thing, as a five-year plan. This person explained how she began attending her gym. It was through my hairdresser. He thought it was a nice gym to go to. He gave me five complimentary sessions. Her father said, The more we get her out there, the more chance there is it will click. 
After network support to establish his own home in a familiar suburb, another person regularly walked to the barber's for a haircut and shave. He bought magazines from a newsagent and belonged to a local community centre. He attended karaoke at a pub, went to the movies, did an exercise program in a nearby park and visited a coffee shop on his way home from work.

Networks evaluated opportunities considering factors such as geography, public transport, cost and accessibility. Complex obstacles were worked through with thought, persistence and creativity. Risk came with independence and this was a concern for network members balancing participation and protection. A mother wondering about safety said she now wants to get her driver's license... The ones playing the loud music with a carload of friends, are they going to be any better [at driving] than she is? Broader social horizons left the person vulnerable to being labeled. The same mother tossed up the benefits of attending an organized, supervised social group. So the benefit of these groups is that she's meeting others. The negative side...if she does go, she's going to be reinforced that she needs a carer.

\section{Creating opportunities}

Sometimes networks discovered that a suitable option did not exist, or did not offer the required amount of autonomy or safety. Network members established programs, groups, organizations and facilities, or altered or expanded an existing opportunity to fit. Opportunities created by networks included soccer days, netball competitions, having a home of one's own, vocational education, overseas travel, a day at the Easter Show, exhibitions, book clubs, personal care support, securing furniture and appliances, health review, community gardening, street soccer and weight-loss programs.

One person played soccer in a competition established twenty years before by the parents of a person with disability. This person also attended a program where the coordinator established and maintained community links to maximize participation.

...we talked to everyone we could talk to. We've got churches on side,...clubs..., council, you name it...people come from everywhere and feel part of it... We join as many things as we can ...we get to know the local businesses... nothing ever in isolation...

A father said that ... [the person] and I drove around Australia in 1999 for ten weeks and so it was a real...road movie sort of thing and experiences, a whole lot of Australia... Network members found a sports scientist who could take the person's diabetes into account when she exercised with him twice a week.

\section{Facilitating access to opportunities}

Sometimes networks brought the community to the person. One network initiated monthly barbecues at home, focusing on karaoke, cricket and humour. The person was not comfortable with more than five or six people and couldn't cope with more than one conversation at a time. His parents invited a few people who would not cut across conversations. The same network organized art exhibitions with opening nights where people came to view and buy the person's artworks.

Frequently, participation for a person was hindered by the values and attitudes of others. Networks took on the task of re-educating and changing attitudes of community members. A mother gave an acquaintance a lift to the doctor's. The receptionist expected the mother to wait there with this man. Why does he need someone? the mother asked the receptionist. He lives by himself in the community, he lives in his own house, he's no different to any of your other patients that come in...But that's an assumption...that these people as the community sees them have to have someone caring for them. 


\section{Providing support in a variety of ways}

Although not comprehensive, Table 4 illustrates the intensity and diversity of support provided across the nine networks.

Table 4: Diversity of support provided by networks

\begin{tabular}{l} 
Area of support \\
\hline Motivation/encouragement \\
Positive expectation/realism \\
Goal-orientation \\
Strategy \\
Back-up/moral support \\
Modeling/mentorship \\
Cheering on/praise
\end{tabular}

\author{
Communication \\ Listening \\ Connecting \\ Staying in touch

\section{Research and ideas \\ Brainstorming \\ Keeping open minds \\ Discussion}

\author{
Practical support \\ Provision of opportunities \\ Creation of opportunities \\ Compensation for support failure \\ Financial \\ Accommodation \\ Occupational/educational \\ Leisure/social \\ Health \\ Transport
}

\author{
Interpersonal support \\ Family \\ Friendship \\ Community support \\ Being there
}

\section{Time and effort \\ Initiation}

Facilitation

Teamwork

Example of support provided

Encouraged social networking skills

Facilitated artwork based on Sistine

Chapel

Established eye-contact and greeting

Encouraged phoning of friends

Attended art studio open day

Prompted safety while walking in city

Praised shopping around before buying a ring

Conversed about moving interstate

Asked 'Is this really what you want to do?'

Arranged bushwalking or cooking sessions

Skyped conversations from overseas

Defined itself as an ideas group

Collected ideas in magazine, log, photo

album

Brought different views to meetings

Centred discussions on goals

Delegated tasks on action sheet

Traveled the buses for two weeks

Supported haircut and shopping in local

area

Prevented forced move out of shared flat

Helped with net banking

Supported move out of parents' home

Held public exhibition of artworks

Arranged a class sleepover

Organised surgery for painful feet

Provided transport to choir practice

Went on road trip round Australia

Visited and helped clean out clothes closet

Evening outings to the local pub

Accepted as part of church community

Helped with meal preparation twice weekly

Filled the gaps left by formal services

Weeded a community garden and used a roster

Opened art exhibition;
speeches/refreshments
Stepped in during crises or absences

By whom

Support worker

Art teacher

Mother

Mother

Network members

Support worker

Support worker

Family/friends

Siblings

Network member

Brother

Network meeting

Network members

Lawyer at gym

Network meeting

Network meeting

Support workers

Support co-ord'r

Sister

Mother

Siblings

Network members

Mother

Mother

Church members

Father

Niece

Flatmates

Church members

Sister-in-law

Mother

Support worker

Mother/network

Family 


\begin{tabular}{|c|c|c|}
\hline Area of support & Example of support provided & By whom \\
\hline Flexibility & Varied activities depending on mood & Support workers \\
\hline Negotiation & Agreed to do the cleaning later & Formal services \\
\hline Compromise & Arranged participation in group social & Mother \\
\hline Getting out of the way & activities & Mother \\
\hline $\begin{array}{l}\text { Overcoming obstacles/problem- } \\
\text { solving }\end{array}$ & $\begin{array}{l}\text { Avoided phoning a future employer } \\
\text { Moved to a different community } \\
\text { participation program }\end{array}$ & Network members \\
\hline Persistence & $\begin{array}{l}\text { Supported to overcome wariness of people } \\
\text { with mental illness }\end{array}$ & Studio director \\
\hline Enthusiasm & Commenced a weight-loss program & Sisters \\
\hline Energy/drive & $\begin{array}{l}\text { Generated energy by discussing a } \\
\text { common goal }\end{array}$ & Network meeting \\
\hline Focus & Knew the person's strengths and dreams & Network members \\
\hline Tirelessness & Were the bottom line in support & Family \\
\hline Positivity & $\begin{array}{l}\text { Accompanied on outings for sensory } \\
\text { experience }\end{array}$ & Support worker \\
\hline Cheerfulness/good humour & Sang and danced while doing housework & Support co-ord'r \\
\hline Fun & $\begin{array}{l}\text { Lunch time BBQ's with cricket, karaoke, } \\
\text { humour }\end{array}$ & Parents \\
\hline Sense of humour & Suggested belly-dancing as a fitness idea & Mother \\
\hline Protection & Voiced concerns about single living & Mother's friend \\
\hline Safety & Hesitated to arrange driving lessons & Mother \\
\hline Rights & Asked a bossy moving helper to go home & Sister \\
\hline
\end{tabular}

Note. Areas of support have been grouped under a bolded specific area of support most representative of that type of support.

\section{Gathering feedback, re-planning and restructuring support}

Close, ongoing contact with the person allowed networks to gather information about obstacles encountered and gains made. Networks re-planned and restructured support, reviewed goals, adapted, compromised, built on success, and overcame obstacles. Persistence, open minds and lateral thinking were essential.

\section{Network strategy: Getting out of the way}

Networks "got out of the way" when it became obvious that the person was becoming more autonomous. Networks often seemed surprised and delighted at the speed and confidence with which each person adapted to new situations and revealed previously unnoticed strengths. Network members adjusted and changed their actions accordingly. A sister mentioned that, away from the family, the person responded to people in a different way. When he is at home he is one person, she says, and then...he said good-bye and he walked away from the car...you saw this shift and he was just this completely different person...he is not often like that with us. This person's family recognised his autonomy and celebrated it; ...we'll go to the pub as a family and he knows five people behind the bar and two others by the pool table that we have no idea who they are, which is great. The family has been careful not to inhibit the person's social flair. This person sometimes took hours to arrive home after work because he visited pubs and cafes on the way. His network did not oversee who he met or what he did on these occasions. Another time, he disappeared and neither his housemates or his family knew where he was. Luckily he now answers his mobile phone so one of the housemates rang and he said, 'Oh, I'm at the game and I'm with [ex-housemate].' He had rung 
the ex-housemate and arranged to meet him at the football. He had the autonomy to arrange the football outing himself and his use of the mobile phone reassured the family about his safety.

Another person wanted to move out of home into a place of her own, but network members had reservations about her ability to cope. After moving out, this person noticed the shopping list kept in the kitchen and went down to the shop on her own to buy her groceries. In the end, says her mother, l've got to shut up; she knows exactly what she's doing. Such insights were celebrated but could be challenging for network members.

\section{Network strategy: Gradual withdrawal of support}

Networks sometimes provided initial support then withdrew it, as the person became proficient. This strategy eased transition and increased success, making participation more comfortable for the person. Sometimes success was not immediate, but network strategies and persistence yielded success. When one person began attending a gym, a network member talked to the gym staff and organised a personal trainer, then ...bit by bit we wean off. Okay, we'll come down with you and we'll pick you up, and then we'll come down with you but you walk back, and then "are you all right to go on your own this week?" So off they go.

\section{Network strategy: Compromise}

Occasionally the person and the network members held differing views. The network may have felt that a goal was out of reach, or saw another goal as crucial, but the person held the opposite view. Discussion and compromise were required when these dilemmas arose. This could be stressful for some network members. One person liked to dress casually. A network member felt that this was not appropriate for every occasion, and consulted with the person. The network member helped sort and care for the person's clothes. On one occasion she persuaded her to change into more suitable attire. She recounted how, unknown to her, the person brought along a t-shirt so that she could change later.

On occasion, network members felt strongly enough to hold out against criticism from outside or other network members. Network members were convinced that in specific situations they knew what was right for the person despite resistance.

A mother explained. The person in the role of advocate needs to...know what you're doing is right...to carry on if you run into a barrier and you could be in a situation, if you don't have the support of people who can help you in being clear about that...where even close family members, not knowing how important it is to pursue the issue, can be critical of what you're doing.

A person was in danger of being moved out of her flat by her service provider so that her flatmate's boyfriend could move in. This brought out protective instincts in network members. [Sister] was so angry with them. [Staffperson] was so rude, who said, "Well, everything's organised and [Person] will move out and [flatmate's boyfriend] will go into the [flat]..." and [sister] said, "No, that's not happening."...that was going to happen with very little input from us,...it was going to be presented as a fait accompli.

\section{Network strategy: Back to the drawing board}

When strategies were not working to promote participation, the network re-planned. Reasons for support difficulties were diverse, ranging from changed circumstances, to an idea not working as well as anticipated. A network arranged swimming lessons, and found a swimming instructor who could change his approach in line with the person's needs. He is a strong, but unconventional, swimmer. [Swim instructor] understood not to push him too hard ...[Person] 
likes frog kick, but not scissor kick. [Swim instructor] gave up trying to get him to scissor kick and concentrated on frog kick. Earlier in this person's life, his family changed the school he attended, so as to promote the cycle of stepping into circles that have less and less disability and more and more of regular interaction, his father said. At the new school, other students talked to the person more.

\section{Support problems}

The most commonly reported reason for failure of support was the inadequate and often misdirected contribution of formal support services. Formal services frequently failed to identify what was meaningful to the person as well as opportunities and suitable strategies to enhance participation, taking a 'one size fits all' approach. Formal services seemed hampered by lack of funding and staffing, inaccurate beliefs and inflexibility of policy both at a personal and organizational level, resulting in inefficient use of resources. Informal support networks in this inquiry, by comparison, had continuity and a deeper understanding of the person, considered broader options, and were willing to dedicate large amounts of time and effort.

Support failure was usually discovered when the person or staff fed back information. Sometimes the person communicated unhappiness to their network, and sometimes the support collapsed altogether. At these times, networks assessed the situation and consulted with the person and the formal support service. Support networks responded in a variety of ways, for example influencing policy, changing the goal or filling the gap that the failure of support had created. For one person, a delivery job evaporated when the driver became afraid that the person might jump out of the van without warning. The father felt the support organization should have worked with the driver and the person's family to resolve the situation. This network continued tirelessly to arrange different work opportunities such as removing posters from power poles and gardening.

A mother commented on her view of the support of formal services. And I guess because of lack of funding and lack of workers or lack of qualified workers or lack of interest... you find yourself in a situation where, 'Gee l've got all these people involved, but where are they?'...they're so frightened of overlapping each other that they all sit back and so consequently there is no real support within the system at all.

\section{Maintenance of the support network}

Essential to the functioning of the network were communication, coordination, sharing of the workload, and recruitment of new members. The unselfish motivation of network members and appreciation of others' contribution were also critical features.

\section{Communicating information}

Network members pooled information about the person and available opportunities. Information was made accessible, and all leads were followed to arrive at successful support strategies. This often occurred when the network was established, and continued as the network evolved. In one network, the support coordinator had done a thorough presentation on how the program had gone in the first seven months ... she had gone through the diary and produced a month-by-month summary of the changes in person]... She handed out several sheets of paper which summarized [person's] progress. She also used examples from her own experiences with him. When another network formed, the person's parents realised that the members did not ...really know what her life is like ...we did an average week in [person's] life, what does every day look like and what is she doing and how does that work...a bit of a snapshot of who [she] is.

\section{Coordinating the network}


Networks coordinated times and dates for meetings or other occasions when extra support would be required. Records were kept, for example meeting minutes, or a goal chart for the person. These were distributed to members. The coordination of these tasks was undertaken by one person or several, to keep the network running smoothly. In one network, ...the coordinator...puts out a monthly newsletter...he does the minutes and tries to remember to send a reminder of the meeting to its members...there were photos from all the different activities [the photo album] is used by different formal support members and by staff to inform them of the things [the person] does, and to facilitate conversation with him... In another network, there was ...an action sheet that comes out of every meeting...as we talk about something and we come up with something...then we moved to what could [the person's] life look like in five years' time and what could we do to get from here to there and we did a brainstorming session and I had butcher's paper and just facilitated that...

\section{Sharing the workload}

Support tasks and roles involve time and hard work. This was daunting for some network members. They assumed different amounts and types of responsibility depending on their qualities and availability. A network member said, ...l just felt from the discussions that day that maybe there was a role for me...in helping people be clearer... about...keeping that focus on [the person]. Network members were motivated to act to achieve participation for the person.....well it's like, what's the action? Who's going to do it? So we're very deliberate with that otherwise it all becomes very wishy-washy and nobody really knows who is going to do what. The father of this person explained the various roles that his daughter's network had instituted. Family in the group are the doers. Most of the things either [her sister] or myself probably do...taken [the person] out somewhere, invited her home...We wanted the inner circle as a think tank... [we planned] an outer circle of people that might relate to [the person] in a friendship, companionship sort of way...

\section{Monitoring motives}

Membership of the network was monitored closely, and confined to people who genuinely cared about the person, without hidden agendas or conflicts of interest. A mother stated ...what is important is having that person who's got that rapport and that understanding and that connection to people to be able to be of assistance rather than just someone who's there getting paid to do a job and don't really care. In addition, members seemed to scrutinize not only the motives of formal service staff, but also those of the person's closest family. A mother warned ...the only danger is if services assume that yes, the family has the best interests of the person at heart, that they don't necessarily, or that those interests might be misguided. Finally, network members carefully examined their own motives. That first gathering of people showed...said a network member ...that some people had a very different idea...more limited idea of what [person's] future could be like and one [of these] ...decided that it wasn't appropriate for her to be in the circle. These conflicts between network members had not always been anticipated, and could take months or years to negotiate. Some conflicts stemmed from the closeness and persistence in a family that was the bedrock for the network's staunch support of the person. There's a need to examine yourself too in how you go about things... said a mother... sometimes you need to adjust the way in which you're doing things because achieving what you want is more important than your own anger...

\section{Supporting individual members}

Members were appreciative of each other's time and input, aware of personal circumstances and offered support and understanding when needed. When circumstances affected network members' contributions, avenues of communication remained open in the hope that the member would eventually contribute again. Sometimes the network member scaled back their 
input to suit their changed circumstances. For example, a mother mentioned when talking about recruitment of network members...the person that's just left the house would be great but she's gone around Australia for a year so she may well be a future member.

\section{Recruiting members}

Networks constantly recruited new members and refined membership. Some networks stayed alert for people who may have had a historic or chance relationship with the person, as well as people with obvious qualifications. Often, the person independently made connections with people who later joined the network. Network members were delighted by the willingness of people inside and outside the family to become involved in planning and support. Some networks developed strategies to manage the large numbers of extended family involved. Some people declined the opportunity due to other commitments. Some network members found the recruitment and management of membership awkward and were hampered by concerns about imposition and rejection. One mother became expert at recruiting all types of people. The brother said of his mother...It's what she does for a job as well, makes people feel relaxed and gets them to open up and feel invited. The same mother described some of the diverse members that comprised the network.

Well [a member] is on the circle, he's gone [overseas] for a couple of years but he wants to be an email member. Our daughter,...she's on [the circle], we're on it, an old friend of our family is on it, a carer who used to look after [person] years and years ago...she's on it and various housemates...ex-carers, people who've worked for various respite organisations, old friends, people who want some sort of community involvement...this young woman, I go to the gym with her and she overheard me talking about it...she's a very high-powered lawyer...

\section{Participation and engagement}

Network support promoted greater participation in tasks, activities and routines in a variety of community contexts. Network support also promoted engagement which was personally meaningful and socially connected. Specific changes that moved the person towards a good life were unique to each individual, and are summarized in Table 5.

Table 5: Support networks promote participation and engagement

\begin{tabular}{ll}
\hline $\begin{array}{l}\text { Aspect of Ramifications } \\
\text { participation }\end{array}$ & Example \\
\hline
\end{tabular}

Diverse role Successful performance in diverse performance roles.

Recognition, by others, of those roles e.g. gardener, artist, parishioner, sister, baby, shopper, friend, fan, road tripper.

Autonomy

Happiness and self-worth
Increased control over life: work, home, leisure.

Definite opinions about choices and management of activities.

Opinions taken seriously by others. e.g. acquired, maintained and discarded possessions.

A better life, appearance of being happy, and greater pleasure in activities.

Decreased stress and better health. ...so I really started thinking about [person] as a football fan...Fans buy magazines. They look at pictures...They go to matches. They talk to their friends about the scores.

After work, two flatmates relaxed with coffee in the lounge room. When a staff person phoned about housework, the person said, We will do it, but not today.

...she loves singing...if you pick her up you got to put the music on and she...sings and dances in the 


\begin{tabular}{|c|c|c|}
\hline & & $\begin{array}{l}\text { car...her soccer...she loves that. } \\
\text { And the art. }\end{array}$ \\
\hline $\begin{array}{l}\text { Participation } \\
\text { and } \\
\text { engagement }\end{array}$ & $\begin{array}{l}\text { Challenges faced with improved skills } \\
\text { and success. } \\
\text { Improved self-esteem led to } \\
\text { independence. }\end{array}$ & $\begin{array}{l}\text { They're able to say, 'I've done that', } \\
\text { and up we go...with that self- } \\
\text { esteem...they start making } \\
\text { incredibly good decisions... }\end{array}$ \\
\hline Relationships & $\begin{array}{l}\text { Extended and diversified social } \\
\text { contacts. } \\
\text { Growth in trust, rapport, and ease of } \\
\text { communication. } \\
\text { Confidence in relationships. }\end{array}$ & $\begin{array}{l}\text { [The person's] ability to read people } \\
\text { and react in an appropriate and } \\
\text { perceptive way is significantly } \\
\text { advanced from where he was twelve } \\
\text { and eighteen months ago. }\end{array}$ \\
\hline Reciprocity & $\begin{array}{l}\text { Expanded network, became part of the } \\
\text { community and supported family and } \\
\text { friends. } \\
\text { Benefited the person, the network and } \\
\text { the wider community. Changed } \\
\text { attitudes in the wider community. }\end{array}$ & $\begin{array}{l}\text {...the circles get wider and } \\
\text { wider...from that self out into their } \\
\text { family, out into the community and } \\
\text { then starting to give back... }\end{array}$ \\
\hline
\end{tabular}

\section{Discussion}

Network members in this study identified an array of factors which impact the participation of people with an intellectual disability. Also, the important relationships between these factors and the subtle and complex ways in which these factors can be mediated to promote a 'good life' for the person. While some of these factors have been identified in previous research (Arvidsson et al., 2008; Axelsson et al., 2014; Briggs, 2017; Forrester-Jones et al., 2006; Meininger, 2013; Verdonschot et al. 2009b), network members in this study described the actual processes and mechanisms involved (Schofield, 2015). Network members valued, looked for and celebrated the person's contribution. They proactively identified and recognized the person's perspective, acting accordingly.

Rather than merely describing the factors which impact on participation, networks in this inquiry actively influenced factors to promote a 'good life'. This included recruiting, in a strategic and effective manner, the creativity, energy, time, resources and expertise of people who were known to them. This increased the available resources in an exponential manner, beyond nuclear family members to a wide range of friends, acquaintances, members of the wider community (accidentally and intentionally recruited) and generic service providers. This range of resources was used to address a wide variety of life experiences, from health and transport to having a home of one's own, a career, pursuing leisure interests and contributing to the community. None of this was easily achieved. Network members were creative and persevered in addressing numerous obstacles including the inflexibility of formal services, discrimination, and lack of financial and other resources. Typically, they responded by returning to the drawing board, clarifying the nature of the obstacles, recruiting new expertise, seeking mentors, and even creating new models of support or new organizations. Networks became skilled at re-conceptualizing the parameters for decision making (Heller et al., 2002). Less recognized factors influencing participation were the importance of identifying, developing and nurturing links and connections within a place or community where you belong, and the time, planning and deliberation that this took (Hillman et al., 2013).

The personal networks demonstrated the capacity to work across diverse levels of participation and experience, from eye contact with a person experiencing post-traumatic stress following serious abuse to regulating insulin delivery, obtaining a driver's license, employment credentials, housing leases, to the creation of an alternative social housing 
model. Also, network members' strategies were as diverse as the levels at which they were working, from holding art exhibitions through building community acceptance, locating and providing employment support, using fun to achieve a goal, to creating opportunities and establishing viable transport options.

Depth of insight and understanding was characteristic of the planning and work of network members. They considered the relationship between risk and autonomy, vulnerability and freedom, and the personhood, importance and dignity of each person at the centre of the network. Links and connections were maintained and supported within the community and within the networks. The wider network was vital to the success of participation and the development of engagement. This is why in some cases networks brought the community to the person, and why vigilant planning and monitoring occurred, of the wider network as well as the support network.

All of these insights were built on the reality of shared relationship. The top down orientation of the networks was focused on meaningful roles, positivity and creating a tone of respect and acceptance (Baum \& Christiansen, 2015; Chapparo \& Ranka, 1997). Networks demonstrated the profoundly relational nature of participation. The processes and mechanisms network members used in promoting the participation of people with intellectual disability will inform efforts to promote social inclusion (Axelsson et al., 2014). This study was limited to the nine families that participated, all living on the eastern seaboard of Australia in inner and outer metropolitan areas. Further work is needed to investigate the barriers and facilitators to personal support network development in rural and regional areas and for people without family members. Recognition of the role that networks play is essential in considering new directions for formal services that would foster strong informal networks and community participation consistent with the current disability reform agenda proposed in the National Disability Insurance Scheme Act 2013 and person centred care (Australian Commission on Quality and Safety in Healthcare, 2011). Most importantly, formal services should avoid harming existing network relationships or creating barriers between network members. Awareness of the diverse obstacles to participation for the person, and the significance of the flexibility and creativity of the network would be crucial.

\section{Acknowledgement}

Families and network members made this research possible. This research was also supported under the Australian Research Council Discovery Project funding scheme (Project number DP0773962). The views expressed herein are those of the authors and are not necessarily those of the Australian Research Council. 


\section{References}

Ager, A., Myers, F., Kerr, P., Myles, S., \& Green, A. (2001). 'Moving home: Social integration for adults with intellectual disabilities resettling into community provision'. Journal of Applied Research in Intellectual Disabilities, 14(4), 392-400.

Amado, A.N., Stancliffe, R.J., McCarron, M. \& McCallion, P. (2013). 'Social inclusion and community participation of individuals with intellectual/ developmental disabilities'. Journal of Intellectual and Developmental Disability, 51(5), 360-375.

Angrosino, M.V. (2005). 'Recontextualizing observation: Ethnography, pedagogy and the prospects for a progressive political agenda'. In N.K. Denzin \& Y.S. Lincoln (eds.), The Sage handbook of qualitative research, pp.729-746. Thousand Oaks, CA: Sage.

Arvidsson, P., Granlund, M. \& Thyberg, M. (2008). 'Factors related to self-rated participation in adolescents and adults with mild intellectual disability - A systematic literature review'. Journal of Applied Research in Intellectual Disabilities, 21(3), 277-291.

Asselt-Goverts, A.E., Embregts, P.J.C.M. \& Hendricks, A.H.C. (2013). 'Structural and functional characteristics of the social networks of people with mild intellectual disabilities'. Research in Developmental Disabilities, 34(4), 1280-1288.

Australian Commission on Safety and Quality in Health Care. (2011). Patient-Centred Care: Improving Quality and Safety Through Partnerships with Patients and Consumers. Retrieved from https://www.safetyandquality.gov.au/our-work/patient-and-consumercentred-care/.

Axelsson, A.K., Imms, C. \& Wilder, J. (2014). 'Strategies that facilitate participation in family activities of children and adolescents with profound intellectual and multiple disabilities: parents' and personal assistants' experiences'. Disability and Rehabilitation,_36(25), 2169-2177.

Baszanger, I. \& Dodier, N. (2004). 'Ethnography: relating the part to the whole'. In D. Silverman (ed.). Qualitative Research: Theory, method and practice ( $2^{\text {nd }}$ ed.) (pp. 9-34). London, UK: Sage.

Baum, C. M. \& Christiansen, C. H. (2015). 'The person-environment-occupation- performance model'. In C. H. Christiansen, C. M. Baum, and J. D. Bass (eds.), Occupational therapy: Performance, participation, and well-being. (4th ed.). Thorofare, NJ: SLACK Incorporated.

Bigby, C. (2008). 'Known well by no-one: Trends in the informal social networks of middleaged and older people with intellectual disability five years after moving to the community'. Journal of Intellectual and Developmental Disability, 33(2), 148-157.

Bigby, C. (2012). 'Social inclusion and people with intellectual disability and challenging behaviour: A systematic review'. Journal of Intellectual and Developmental Disability, 37(4), 360-374.

Briggs, L. \& Harris, P. (2017). 'A brief foray into social inclusion- what does it mean for professional health practice?' Journal of Social Inclusion, 8(1), 96-103.

Chapparo, C. \& Ranka, J. (1997). The occupational performance model (Australia): Monograph 1. Place of publication: Occupational Performance Network.

Charmaz, K. (2005). 'Grounded theory in the $21^{\text {st }}$ century: Applications for advancing social justice studies'. In N.K. Denzin \& Y.S. Lincoln (eds.), The Sage handbook of qualitative research (pp. 507-536). Thousand Oaks, CA: Sage.

Clarke, A. E. (2005). Situational analysis: Grounded theory after the post modern turn. Thousand Oaks, CA: Sage.

Clement, T. \& Bigby, C. (2009). Breaking out of a distinct social space: Reflections on supporting community participation for people with severe and profound intellectual disability. Journal of Applied Research in Intellectual Disabilities, 22(3), 264-275.

Corbin, J. M. \& Strauss, A. (2008). Basics of qualitative research: Techniques and procedures for developing grounded theory. ( $3^{\text {rd }}$ ed.). Los Angeles, CA: Sage. 
Cordier R., Milbourn B., Martin R., Buchanan A., Chung D. \& Speyer, R, (2017). 'A systematic review evaluating the psychometric properties of measures of social inclusion'. PLOS ONE 12(6), e0179109.

Cummins, R. A. \& Lau, A. L. D. (2003). 'Community integration or community exposure? A review and discussion in relation to people with an intellectual disability'. Journal of Applied Research in Intellectual Disabilities, 16(2), 145-157.

Donelly, M., Hillman, A., Stancliffe, R.J., Knox, M., Whitaker, L. \& Parmenter, T.R. (2010). 'The role of informal networks in providing effective work opportunities for people with an intellectual disability'. Work, 36(2), 227-237.

Emerson, E. (2011). 'Health status and health risks of the "hidden majority" of adults with intellectual disability'. Intellectual and Developmental Disabilities, 49(3), 155-165.

Etmanski, A. (2004). A good life: For you and your relative with a disability (2 $2^{\text {nd }}$ ed.). Vancouver, B.C.: Orwell Cove and Planned Lifetime Advocacy Network.

Fontana, A. \& Frey, J.H. (2005). 'The interview: From neutral stance to political involvement'. In N.K. Denzin \& Y.S. Lincoln (eds.), The Sage handbook of qualitative research (pp. 695-728). Thousand Oaks, CA: Sage.

Forrester-Jones, R., Carpenter, J., Coolen-Schrijner, P., Cambridge, P., Tate, A. \& Beecham, J. (2006). 'The social networks of people with intellectual disability living in the community 12 years after resettlement from long-stay hospitals'. Journal of Applied Research in Intellectual Disabilities, 19(4), 285-295.

Glaser, B.G. \& Strauss, A. (1967). The discovery of grounded theory: Strategies for qualitative research. London, UK: Weidenfeld \& Nicolson.

Grbich, C. (2007). Qualitative data analysis. London: Sage.

Guba, E.G. \& Lincoln, Y.S. (2005). 'Paradigmatic controversies, contradictions and emerging confluences'. In N.K. Denzin \& Y.S. Lincoln (eds.), The Sage handbook of qualitative research (pp. 191-216). Thousand Oaks, CA: Sage.

Holstein, J.A. \& Gubrium, J.F. (2004). 'The active interview'. In D. Silverman (ed.), Qualitative Rresearch: Theory, method and practice ( $2^{\text {nd }}$ ed.,) (pp. 140-161). London, UK: Sage.

Heller, T., Miller, A. B. \& Hsieh, K. (2002). 'Eight-year follow-up of the impact of environmental characteristics on well-being of adults with developmental disabilities'. Mental Retardation, 40(5), 366-378.

Hillman, A., Donelly, M., Dew, A., Stancliffe, R.J., Whitaker, L., Knox, M., Shelley, K. \& Parmenter, T.R. (2013). 'The dynamics of support over time in the intentional support networks of nine people with intellectual disability', Disability \& Society, 28(7), 922936.

laquinto, L. (2016). 'Making participation accessible for vulnerable clients'. Journal of Social Inclusion, 7, 1, 85-97.

Iwama, M.K. (2006). The Kawa Model. New York: Churchill Livingstone.

Knox, H., Savage, M. \& Harvey, P. (2006). 'Social networks and the study of relations: Networks as method, metaphor and form'. Economy and Society, 35(1), 113-140.

Kozma, A., Mansell, J. \& Beadle-Brown, J. (2009). 'Outcomes in different residential settings for people with intellectual disability: A systematic review'. American Journal on Intellectual and Developmental Disabilities, 114(3), 193-222.

Kronenberg, F., Algado, S.S. \& Pollard, N. (2004). Occupational therapy without borders: Learning from the spirit of survivors. Edinburgh, UK: Churchill Livingstone.

Marmot, M. (2005). 'Social determinants of health inequalities'. The Lancet. 365(9464), 10991104.

McConkey, R. \& Collins, S. (2010). 'The role of support staff in promoting the social inclusion of persons with an intellectual disability'. Journal of Intellectual Disability Research, 54(8), 691-700.

McVilly, K.R., Stancliffe, R.J., Parmenter, T.R. \& Burton-Smith, R.M. (2006). 'I get by with a little help from my friends: Adults with intellectual disability discuss loneliness'. Journal of Applied Research in Intellectual Disabilities, 19(2), 191-203.

Meininger, H. (2013). 'Inclusion as heterotopia: Spaces of encounter between people with and without intellectual disability'. Journal of Social Inclusion, 4(1), 24-44. 
Miles, M.B. \& Huberman, M. (1984). Qualitative data analysis: A sourcebook of new methods. Beverly Hills, CA: Sage.

Milner, P. \& Kelly, B. (2009). 'Community participation and inclusion: People with disabilities defining their place'. Disability and Society, 24(1), 47-62.

Myers, F., Ager, A., Kerr, P. \& Myles, S. (1998). 'Outside looking in? Studies of the community integration of people with learning disabilities'. Disability \& Society, 13(3), 389-413.

O'Brien, J. (1987). 'A guide to life-style planning: Using the activities catalog to integrate services and natural support systems'. In B. Wilcox \& G. Bellamy (eds.), The activities catalogue: An alternative curriculum for youth and adults with severe disabilities (pp. 175-189). Baltimore, MD: Brooks.

O'Brien, J. (1999). Community Eengagement: A necessary condition for self-determination and individual funding. Paper presented at the Community Engagement Working Group.

Oliver, M. (1990). The politics of disablement. London: Macmillan Education.

Ouellette-Kuntz, H., Burge, P., Brown, H. K. \& Arsenault, E. (2010). 'Public attitudes towards individuals with intellectual disabilities as measured by the concept of social distance'. Journal of Applied Research in Intellectual Disabilities, 23(2), 132-142.

Resourcing Families (2015). Circles of support: A manual for getting started. Epping, NSW: FamilyAdvocacy.

https://www.ric.org.au/assets/Uploads/70239/ufiles/Circles_of_Support_Manual_201 5.pdf y.

Schofield, T. (2015). A sociological approach to health determinants. Cambridge, MA: Cambridge University Press.

Simplican, S.C., Leader, G., Kosciulek, J. \& Leahy, M. (2015). 'Defining social inclusion of people with intellectual and developmental disabilities: An ecological model of social networks and community participation'. Research in Developmental Disabilities, 38, 18-29.

Somerville, P. (1998). 'Explanations of Social Exclusion: Where Does Housing Fit in?', Housing Studies, 13(6), 761-780.

Snow, Judith, A. (1998). What's Really Worth Doing and How to do it - A Book For People Who Love Someone Labeled Disabled (Possibly Yourself), Inclusion Press, Ontario Canada.

Spradley, J.P. (1979). The ethnographic interview. New York, NY: Holt, Rinehart \& Winston.

Spradley, J.P. (1980). Participant observation. New York, NY: Holt, Rinehart \& Winston.

Strauss, A.L. (1987). Qualitative analysis for social scientists. Cambridge, MANY: Cambridge University Press.

Tedlock, B. (2005). 'The observation of participation and the emergence of public ethnography'. In N.K. Denzin \& Y.S. Lincoln (eds.), The Sage handbook of qualitative research (pp 467-482). Thousand Oaks, CA: Sage.

Van Alphen, L.M., Dijker, A.J.M., Van Den Borne, B.H.W., \& Curfs, L.M.G. (2010). 'People with intellectual disability as neighbours: Towards understanding the mundane aspects of social integration'. Journal of Community \& Applied Social Psychology, 20(5), 347362.

Verdonschot, M.M.L., de Witte, L.P., Reichrath, E., Buntinx, W.H.E. \& Curfs, L.M.G. (2009a). 'Community participation of people with an intellectual disability: A review of empirical findings'. Journal of Intellectual Disability Research, 53(4), 303-318.

Verdonschot, M.M.L., de Witte, L.P., Reichrath, E., Buntinx, W.H.E. \& Curfs, L.M.G. (2009b). 'Impact of environmental factors on community participation of persons with an intellectual disability: A systematic review'. Journal of Intellectual Disability Research, 53(1), 54-64.

World Health Organisation (WHO). (2001). International classification of functioning, disability and health. Geneva, $\mathrm{CH}$ : World Health Organization.

Yazbeck, M., McVilly, K. \& Parmenter, T.R. (2004). 'Attitudes toward people with intellectual disabilities: An Australian perspective'. Journal of Disability Policy Studies, 15(2), 97111. 
Zakrajsek A.G., Hammel J. \& Scazzero, J.A. (2014). 'Supporting people with intellectual and developmental disabilities to participate in their communities through support staff pilot intervention'. Journal of Applied Research Intellectual Disability, 27(2),154-62.

\section{Biographical Notes}

Ms Kathy Shelley was formerly a Research Officer in the Living a Good Life research team, an invited lecturer in the Faculty of Health Sciences, University of Sydney. Research and clinical interests include social inclusion; establishing guidelines for safe transport seating; recognition, respect and entitlements of people with a disability and person-centred support.

Associate Professor Michelle Donelly is the co-coordinator of Allied Health Honours programs in the School of Health and Human Sciences at Southern Cross University. Her research interests include lived experience and the ecology of human participation, engagement; social inclusion and inclusive communities; and advocacy.

Dr Anne Hillman was formerly a Senior Research Fellow in the Living a Good Life research team and lecturer in the Faculty of Health Sciences, University of Sydney. Anne's research interests include changes in performance and occupational roles associated with the lifespan trajectory and role partnerships and a range of ecological factors influencing well-being.

Dr Angela Dew is a sociologist and Senior Research Fellow with the Intellectual Disability Behaviour Support Program at University of NSW, Sydney. Her research interests include the lived experiences of people with a disability and their family members including siblings and the challenges experienced by people with disability and carers living and working in rural areas.

Dr Louise Whitaker teaches in social welfare/ work at Southern Cross University. Her research interests include social welfare and social work education and theorising, developing innovative strategies that respond to the needs of diverse communities.

Professor Roger Stancliffe is Professor of Intellectual Disability at The University of Sydney's Centre for Disability Research and Policy. He is a Fellow of the American Association on Intellectual and Developmental Disabilities (AAIDD) and the International Association for the Scientific Study of Intellectual and Developmental Disabilities (IASSIDD).

Dr Marie Knox is a Senior Research Fellow at the Centre for Disability Studies at the University of Sydney. Research interests include the critical and emancipatory role of research in the un-silencing of the voices of people with disabilities; collaborative research with people with disabilities; citizenship and families.

Professor Emeritus Trevor R. Parmenter held the Foundation Chair of Developmental Disability and was Director of the Centre for Disability Studies in the University of Sydney from 1997-2009. His continuing research interests span the life cycle of people with developmental disabilities. He is a past president of the International Association for the Scientific Study of Intellectual and Developmental Disabilities (IASSIDD). 